\title{
Modulatory Effect of Wheat Germ Oil on Intestinal Oxidative Stress and DNA damage Induced by Carbon tetrachloride in Mice
}

\author{
Hanan Saleh \\ Zoology Department, Faculty of Science, Cairo University, 12316, Giza, Egypt.
}

\section{ARTICLE INFO}

Article history:

Received on: 14/07/2016

Revised on: 17/08/2016

Accepted on: 02/09/2016

Available online: 28/12/2016

Key words:

$\mathrm{CCl}_{4}$; wheat germ oil; small

intestine; lipid profile; DNA damage.

\begin{abstract}
Background/Aim: The liver is continuously linked to the gut via the portal vein supply. Gastrointestinal complications are directly associated with liver cirrhosis. Carbon tetrachloride $\left(\mathrm{CCl}_{4}\right)$ caused liver toxicity is well documented in animal models, the very fewer search has been carried out on the intestinal damage in case of acute liver injury. Thus, this study aimed to investigate the intestinal alteration and subsequently the potential therapeutic role of Wheat Germ Oil (WGO) in the liver and small intestine after acute administration of $\mathrm{CCl}_{4}$. Material and Methods: Mice were randomly divided into 4 groups; control group, WGO group: received corn oil orally for 2 days then WGO $(1400 \mathrm{mg} / \mathrm{kg})$ orally for 8 days, $\mathrm{CCl}_{4}$ group: received $\mathrm{CCl}_{4}$ orally for 2 days then corn oil for 8 days, $\mathrm{CCl}_{4}+\mathrm{WGO}$ group: received $\mathrm{CCl}_{4}$ for 2 days then WGO for 8 days. Serum lipid profile, serum lactate dehydrogenase $(\mathrm{LDH})$, intestinal oxidative stress enzymes, histopathological and DNA fragmentation assays were estimated. Results: Acute dose $\left(50 \%, 1 \mathrm{~mL} / \mathrm{kg}\right.$ body weight) of $\mathrm{CCl}_{4}$-induced hyperlipidemia, hypocholesteremia, elevation in LDH, malondialdehyde (MDA), nitric oxide (NO) and intestinal DNA damage in addition to the reduction in the intestinal oxidative stress markers and an alteration in the mucosal architecture. On the contrary, WGO administration has the potency to protect not only the liver but also the small intestine in acute $\mathrm{CCl}_{4}$-induced tissue damage. The valuable effect is chiefly attributed to its mechanism of reducing the lipid profile and suppressing the oxidative stress that caused DNA damage Conclusion: WGO administration could markedly improve the liver and the small intestine from the $\mathrm{CCl}_{4}$ damage and consequently may be used as a therapeutic agent against the hepatic and intestinal toxicity.
\end{abstract}

\section{INTRODUCTION}

Carbon tetrachloride $\left(\mathrm{CCl}_{4}\right)$ is commonly used for experimental induction of liver injury in rodents to mimic the oxidative stress situations in many pathophysiological conditions (Zhu et al., 2013; Go et al., 2016). The single acute dose of $\mathrm{CCl}_{4}$ causes liver toxicity that is characterized by hepatocellular necrosis and steatosis while a chronic dose of $\mathrm{CCl}_{4}$ causes liver cirrhosis. Generation of free radicals has been observed in many tissues; liver, kidney, intestine, heart, lung, brain, and blood after $\mathrm{CCl}_{4}$ administration (Dashti et al., 1989). The free radicals generated from $\mathrm{CCl}_{4}$ and its metabolites induced an impairment of the endoplasmic reticulum (ER) and altered the permeability

* Corresponding Author

Email: hebead@sci.cu.edu.eh of the mitochondrial membrane, which leads to accumulation of lipids, reduction of protein synthesis and overproduction of the oxidative stress (Weber et al., 2003). Oxidative stress exhibits a significant role in the pathogenesis of liver injury and other hepatic alterations through implications between free radicals generated by $\mathrm{CCl}_{4}$ and lipid peroxidation (Gutiérrez et al., 2010). The toxicity of $\mathrm{CCl}_{4}$ is originated through its breakdown to the highly reactive trichloromethyl radical $\left(\mathrm{CCl}_{3}{ }^{\circ}\right)$ in the endoplasmic reticulum by cytochrome $\mathrm{P}_{450}$ enzymes. $\mathrm{CCl} 3^{\circ}$ which rapidly reacts with oxygen forming trichloromethyl peroxy radical $\left(\mathrm{CCl}_{3} \mathrm{OO}^{\circ}\right)$, that interacts with lipids causing lipid peroxidation that leads to hepatotoxicity (Risal et al., 2012). The free radicals produced from $\mathrm{CCl}_{4}$ not only affect the cellular permeability of the hepatocytes leading to the elevation of hepatic enzymes but also cause deterioration in hepatic function through an elevation in lipid profile such as total lipids, triglycerides, cholesterol and HDL-cholesterol (Essawy et al., 2012). 
The gut and the liver are bidirectionally communicated together through digestion and absorption products, bile, hormones and inflammatory mediators (Bajaj et al., 2012). The correlation between liver damage and the functional integrity of the intestine was documented by (Manevska 1975). As long as the gastrointestinal tract is affected, the mucosal alterations may arise, resulting in portal hypertension during liver cirrhosis (Llovet et al., 1994). Oxygen free radicals generated from $\mathrm{CCl}_{4}$ play an important role in the damage of gut epithelial cells, which may affect the gut barrier function, facilitate bacterial translocation and induce the release of endotoxin (Ramachandran et al., 2002). Oxidative stress in the intestinal mucosa caused an elevation in xanthine oxidase which is an important source of free radicals in the small intestine (Watkins 2001).

Moreover, numerous herbal antioxidants could protect organs against $\mathrm{CCl}_{4}$ induced oxidative stress by reducing lipid peroxidation and restoring the antioxidant enzymes activities. The essential oils including WGO have attracted much attention in recent years due to their unique nutritional value (Majzoobi et al., 2016). WGO has a high amount of policosanol contents specially octacosanol, which reduces the cholesterol levels and improves the lipid profile (Anwar et al., 2015). WGO plays an important role in decreasing lipid peroxidation by activating the tocopherol redox-system (Leenhardt et al., 2008), as an interesting source of natural antioxidant tocopherols, sterols, and vitamin B complex. In addition, WGO has a high vitamin $\mathrm{E}$ and phenolic contents which act as inhibitors of the oxidation processes in body tissues and protect cells against the damaging effects of free radicals generated from $\mathrm{CCl}_{4}$ (Liu et al., 2015 ).

Moreover, WGO not only prevents autoxidation of unsaturated fatty acids but also, confers DNA protective effects (Gelmez et al., 2009). Although the effect of WGO on improving liver toxicity is well documented. However, very few research has been carried out on the intestinal alterations in the case of acute liver injury.

Thus, the aim of this study was carried out to investigate the effect of acute oral dose of $\mathrm{CCl}_{4}$ not only on the liver injury but also on the redox balance of the intestinal mucosa by assessing different levels of the oxidative stress, histopathological changes, and the intestinal DNA damage. It also aims to evaluate the potential role of WGO in preventing the deleterious effects of the $\mathrm{CCl}_{4}$-induced acute liver injury in mice.

\section{MATERIALS AND METHODS}

\section{Animals and chemicals}

Male C57 BL/6 mice (6 weeks old, weighing 22-25 g) were obtained from National Research Center (NRC, Giza, Egypt). Mice were randomly grouped and housed in a conventional clean facility. All the experimental procedures were carried out in accordance with international guidelines for the care and use of laboratory animals. Mice were given food and water ad libitum and maintained in a friendly environment with a $12 \mathrm{~h} / 12 \mathrm{~h}$ lightdark cycle at room temperature $\left(22^{\circ} \mathrm{C}-25^{\circ} \mathrm{C}\right)$. Mice were adapted to laboratory conditions for 7 days before beginning of the experiment. $\mathrm{CCl}_{4}, \mathrm{WGO}$, and all other chemicals were purchased from Sigma-Aldrich Biotechnology (St Louis, MO, USA). Assays kits for the detection of liver lipid profile and oxidative stress markers were purchased from Biodiagnostic (Giza, Egypt).

\section{Induction of liver injury and WGO administration}

Induction of liver injury in mice was done by oral administration of $\mathrm{CCl}_{4}(50 \%, 1 \mathrm{~mL} / \mathrm{kg}$ body weight $)$ dissolved in corn oil, the dose was chosen to induce liver injury as previously reported (Srivastava et al., 2010). WGO was given to the animals by oral gavage at dose (1400 mg/kg body weight), according to previous literature (Karabacak et al., 2011).

\section{Experimental design \\ Mice were randomly divided into 4 groups $(6$ mice/group):}

Group 1: Control group: mice received I $\mathrm{mL}$ oral administration of corn oil for 10 days.

Group 2: WGO group, mice received corn oil orally for 2 days then WGO (1400mg/kg b.w) for 8 days.

Group 3: $\mathbf{C C l}_{\mathbf{4}}$ group, mice received $\mathrm{CCl}_{4}$ dissolved in corn oil orally for 2 days then received corn oil for 8 days.

Group 4: $\mathbf{C C l}_{\mathbf{4}}+\mathbf{W G O}$ group, mice received $\mathbf{C C l}_{4}$ dissolved in corn oil orally for 2 days then received WGO for 8 days

\section{Animal handling}

At the end of the $10^{\text {th }}$ day, all the mice were euthanized after anesthesia; blood samples were collected and centrifuged at $2000 \mathrm{~g}$ for $20 \mathrm{~min}$. Serum was stored at $-20^{\circ} \mathrm{C}$ until used for biochemical assays. The small intestine was removed and immediately divided into two parts: the first part was stored at $80^{\circ} \mathrm{C}$ for biochemical studies and DNA fragmentation while the second part was suspended in $10 \%$ formal saline for fixation preparatory to histological processing.

\section{Small intestine homogenate preparation}

Small intestines were homogenized $(10 \% \mathrm{w} / \mathrm{v})$ in icecold $0.1 \mathrm{M}$ Tris- $\mathrm{HCl}$ buffer ( $\mathrm{pH} 7.4)$. The homogenate was centrifuged at $2000 \mathrm{~g}$ for $15 \mathrm{~min}$ at $4^{\circ} \mathrm{C}$ and the resultant supernatant was used for the biochemical analyses.

\section{Biochemical analysis of serum lipid profile}

The appropriate kits (Bio-Diagnostic, Dokki, Giza, Egypt) were used for the determination of total lipids (Zöllner et al., 1962), triglycerides (Stein et al., 1960), serum total cholesterol and high-density lipoprotein -cholesterol (Tietz et al., 1995) according to the manufacturer's instructions. Then, the concentration of LDL-cholesterol was calculated according to Friedewald's formula (Friedewald et al., 1972). LDL-cholesterol 
$(\mathrm{mg} / \mathrm{dL}) .=$ Serum total cholesterol $-($ Triglycerides $/ 5)-\mathrm{HDL}$ cholesterol. Very low-density lipoprotein (VLDL) was calculated using the following formula: VLDL=Triglycerides $/ 5$.

\section{Lactate dehydrogenase (LDH)}

LDH activity as a marker of tissue injury was measured in the serum spectrophotometrically using commercially available kits (Salucea, Haansberg, Netherlands). LDH activity and expressed by U/L ultraviolet kit (Salucea, Haansberg, Netherlands) (Van der Heiden et al., 1994)

\section{Oxidative stress assessment Malondialdehyde (MDA) assay}

The tissue content of MDA, an index of oxidative stressmediated tissue lipid peroxidation, was determined by the thiobarbituric acid (TBA) method, as described previously (Ohkawa et al., 1979). The small intestine was homogenized with ice-cold $0.1 \mathrm{M}$ Tris- $\mathrm{HCl}$ buffer $(\mathrm{pH} 7.4)$ and the values of MDA in tissue homogenate were expressed as $\mathrm{nmol} / \mathrm{g}$ tissue.

\section{Reduced glutathione (GSH) and Glutathione-S-transferase (GST) of the small intestinal tissue}

GSH and GST play a major role in protecting cells against damage from reactive oxygen species (ROS). Tissue GSH (mg/g tissue) and GST (nmol/min/g tissue) were assessed in the homogenate according to the manufacturer's instructions (Habig et al., 1974; Beutler et al., 1963) respectively.

\section{Superoxide dismutase (SOD) assay}

The method of measuring the SOD activity depends on the inhibition of nitro blue tetrazolium (NBT) reduction by xanthine-xanthine oxidase after addition of superoxide dismutase (Nishikimi et al., 1972). SOD activity was expressed as unit/g of the intestinal tissue.

\section{Catalase (CAT) assay}

The catalase activity in the intestinal tissue was determined by the method described by Aebi (1984), in which the supernatant was incubated with $\mathrm{H}_{2} \mathrm{O}_{2}$ for one minute, and then the reaction was stopped with catalase inhibitor. The color intensity of the complex formed by chromophore and $\mathrm{H}_{2} \mathrm{O}_{2}$ was inversely proportional to the amount of catalase in the sample and measured at $510 \mathrm{~mm}$. CAT activity was expressed as unit/g of the intestinal tissue (Aebi 1984)

\section{Nitric Oxide (NO') assay}

Nitric oxide $\left(\mathrm{NO}^{\circ}\right)$ is a free radical, an uncharged molecule with an unpaired electron. The reaction of $\mathrm{NO}^{\circ}$ with oxygen or other free radicals generates reactive nitrogen species (RNS), which cause multiple biological effects. Nitrite was estimated colorimetrically with the Griess reagent (Montgomery et al., 1961). The content of nitric oxide in the tissue was measured at $540 \mathrm{~nm}$ and expressed as umol/L.

\section{Histopathological preparation}

The small intestines were fixed in $10 \%$ neutral buffered formalin solution and embedded in paraffin wax blocks. Sections of $5 \mu \mathrm{m}$ thickness were stained with hematoxylin and eosin (H\&E) then examined under light microscope for determination of pathological changes (Meyer 1903)

\section{DNA fragmentation assay}

Apoptosis is characterized by DNA fragments that are produced as a result of the endonucleolytic attack. According to Sambrook's protocol (Sambrook et al., 1989), the intestinal tissues were homogenized in lysis buffer $(10 \mathrm{mM}$ Tris-HCl, $\mathrm{pH} 7.4,10$ $\mathrm{mM}$ EDTA and $0.2 \%$ triton-100x) for $20 \mathrm{~min}$ on ice before centrifugation, and digested with proteinase- $\mathrm{K}$ at $50^{\circ} \mathrm{C}(50 \mathrm{mg} / \mathrm{ml})$ for $2 \mathrm{~h}$. After digestion, DNA was extracted three times with phenol-chloroform and precipitated finally with absolute alcohol and $2.5 \mathrm{M}$ sodium acetate $(\mathrm{pH} 4.0)$, then centrifuged at $5000 \mathrm{~g}$ for 30 min. DNA was washed three times with $70 \%$ ethanol dissolved in TE buffer $(\mathrm{pH} 8.0)$ and digested for $15 \mathrm{~min}$ at $37^{\circ} \mathrm{C}$ with DNAse-free RNAse-A (1 $\mu \mathrm{g} / \mathrm{ml})$. DNA was re-extracted in chloroform and reprecipitated with absolute ethanol and $2.5 \mathrm{M}$ sodium acetate ( $\mathrm{pH} 4.0)$.

A specific quantity $(15 \mathrm{mg} / \mathrm{lane})$ was loaded onto an agarose gel. DNA laddering was determined by a constant voltage $(60 \mathrm{~V})$ on a $1.2 \%$ agarose gel containing $0.4 \mathrm{mg} / \mathrm{ml}$ ethidium bromide. The gel was illuminated and photographed under UV light to record DNA fragmentation.

\section{Statistical analysis}

Data are expressed as mean \pm SE of six mice in each group. Treated groups were compared with control and $\mathrm{CCl}_{4}$ group by using Unpaired Student's t-test $* P<0.05,{ }^{* * *} P<$ 0.01 vs control group, ${ }^{\#} P<0.05 ;{ }^{\# \#} P<0.01$ vs $\mathrm{CCl}_{4}$. SPSS, for Windows (USA, version 19.0) was used for the statistical analysis.

\section{RESULTS}

\section{Serum lipid profile}

Data recorded in Table 1 reports a significant increase $(P$ $<0.01)$ in the serum levels of total lipids, triglycerides, total cholesterol, LDL-cholesterol and VDL-cholesterol in $\mathrm{CCl}_{4}$ group as compared to the corresponding control group. However, $\mathrm{CCl}_{4}$ treatment significantly decreased $(P<0.01)$ serum HDLcholesterol in comparison to control group. On the other hand, oral administration of WGO for $\mathrm{CCl}_{4}$ treatment group resulted in a significant decrease $(P<0.01)$ of total lipids, triglycerides, total cholesterol, LDL-cholesterol and VDL-cholesterol levels and significant increase of HDL-cholesterol as compared to the corresponding $\mathrm{CCl}_{4}$ treatment group. 
Table 1: Effect of WGO on serum lipid profile in mice treated with $\mathrm{CCl}_{4}$

\begin{tabular}{|c|c|c|c|c|c|c|}
\hline Groups & $\begin{array}{l}\text { Total Lipids } \\
(\mathbf{m g} / \mathrm{dL})\end{array}$ & $\begin{array}{l}\text { Triglycerides } \\
\quad(\mathrm{mg} / \mathrm{dL})\end{array}$ & $\begin{array}{c}\text { Total } \\
\text { cholesterol } \\
(\mathrm{mg} / \mathrm{dL})\end{array}$ & $\begin{array}{c}\text { HDL- } \\
\text { cholesterol } \\
(\mathrm{mg} / \mathrm{dL})\end{array}$ & $\begin{array}{c}\text { LDL- } \\
\text { cholesterol } \\
(\mathrm{mg} / \mathrm{dL})\end{array}$ & $\begin{array}{c}\text { VLDL-cholesterol } \\
\text { (mg/dL) }\end{array}$ \\
\hline Control & $591.90 \pm 56.26$ & $113.91 \pm 1.63$ & $120.52 \pm 2.99$ & $69.26 \pm 0.72$ & $32.64 \pm 2.68$ & $21.16 \pm 0.53$ \\
\hline WGO & $425.43 \pm 40.54$ & $111.7 \pm 2.36$ & $111.7 \pm 3.33$ & $72.86 \pm 2.15$ & $25.66 \pm 1.01$ & $23.14 \pm 0.25$ \\
\hline $\mathrm{CCl}_{4}$ & $1108 \pm 56.26^{* *}$ & $153.70 \pm 2.35^{* *}$ & $166.20 \pm 9.42^{* *}$ & $33.90 \pm 1.26^{* *}$ & $94.23 \pm 3.332^{* *}$ & $30.73 \pm 0.44^{* *}$ \\
\hline $\mathrm{CCl}_{4}+\mathrm{WGO}$ & $468.5 \pm 39.27^{\# \#}$ & $115.63 \pm 5.05^{\# \#}$ & $128.80 \pm 3.09^{\# \#}$ & $61.33 \pm 1.14^{\# \#}$ & $44.35 \pm 2.810^{\# \#}$ & $23.13 \pm 1.01^{\# \#}$ \\
\hline
\end{tabular}

Data are expressed as mean $\pm \mathrm{SE} ;(\mathrm{n}=6)$. Significant difference is indicated by ${ }^{*} P<0.05 \&{ }^{* *} P<0.01$ vs control group and ${ }^{\#} P<0.05 \&{ }^{\# \#} P<0.01$ vs $\mathrm{CCl}_{4}$.

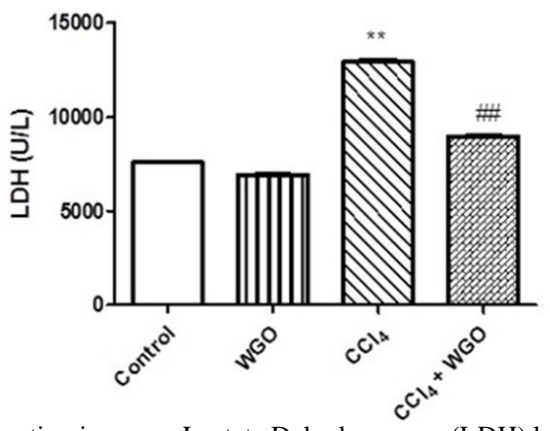

Fig. 1: Effect of WGO on $\mathrm{CCl}_{4}$-induced elevation in serum Lactate Dehydrogenase (LDH) levels as an index of general tissue damage.
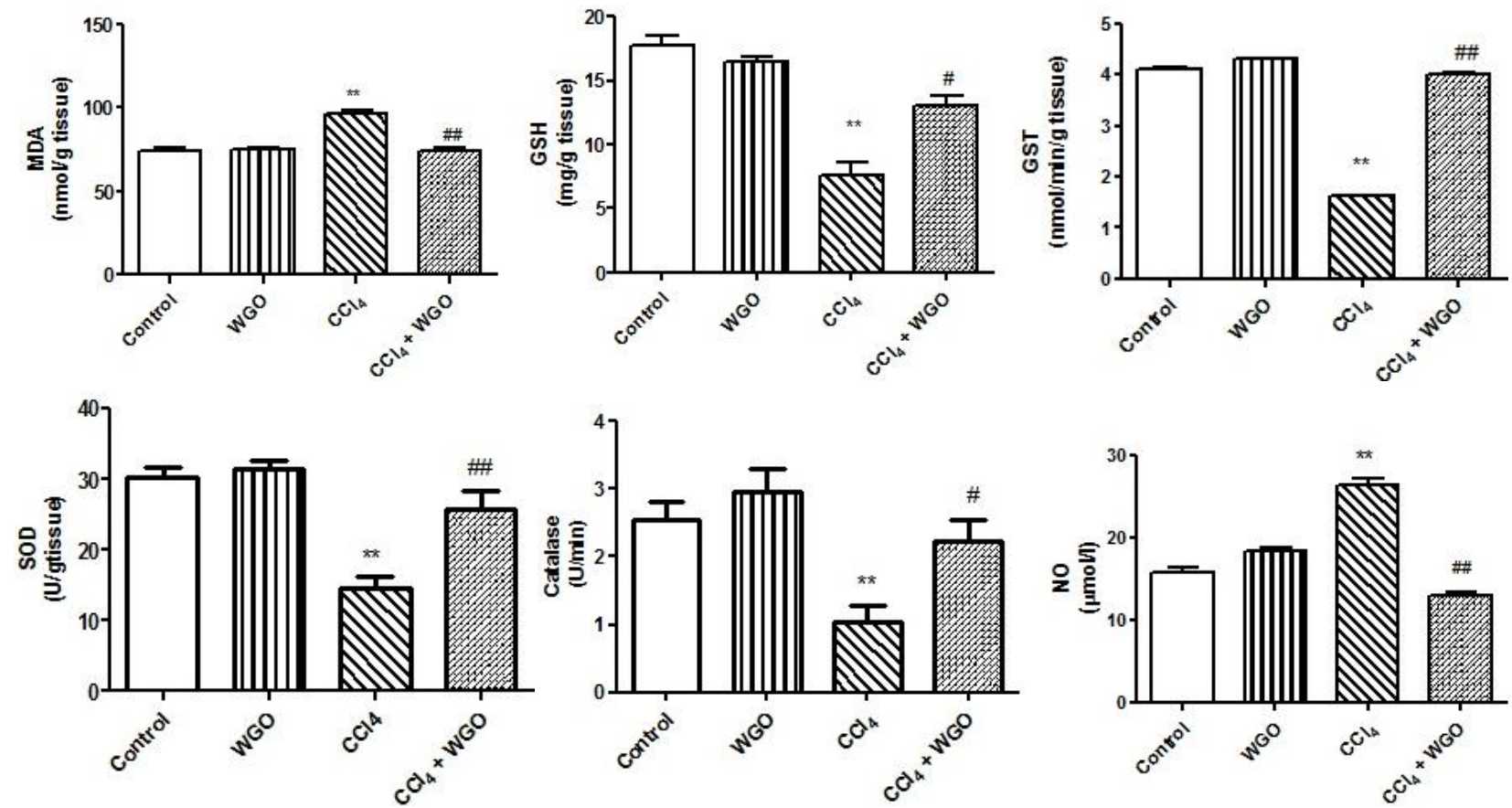

Fig. 2: Effect of $\mathrm{WGO}$ on $\mathrm{CCl}_{4}$-induced changes in antioxidant markers of the small intestine

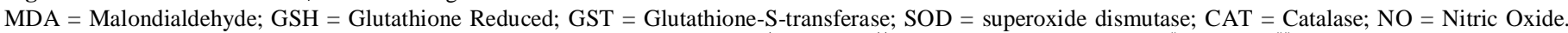

Data are expressed as mean $\pm \mathrm{SE} ;(\mathrm{n}=6)$. Significant difference is indicated by ${ }^{*} P<0.05 \&{ }^{* * *} P<0.01$ vs control group and ${ }^{\#} P<0.05 \&{ }^{\# \#} P<0.01$ vs $\mathrm{CCl}_{4}$

\section{Lactate dehydrogenase (LDH)}

To evaluate the cellular injury, LDH was measured spectrophotometrically in the serum. Serum LDH was found to be elevated significantly $(P<0.01)$ after $\mathrm{CCl}_{4}$ treatment as compared to the control group, whereas WGO administration resulted in a significant attenuation of LDH level $(P<0.01)$ (Figure 1).

\section{Intestinal oxidative stress}

The current study revealed that MDA and NO levels were increased significantly $(P<0.01)$ in $\mathrm{CCl}_{4}$-treated mice as compared to the control group. While, a significant decrease $(P<$ 0.05 ) in the levels of GSH, GST, SOD and CAT were observed in the $\mathrm{CCl}_{4}$-treated group. In contrast, the levels of MDA and NO were decreased significantly in $\mathrm{CCl}_{4}+\mathrm{WGO}$ group when compared to the $\mathrm{CCl}_{4}$-treated group.

On the other hand, a significant increase in concentrations of GSH and CAT $(P<0.05)$, and GST, SOD $(P<$ 0.01 ) were observed subsequent to the oral administration of WGO after $\mathrm{CCl}_{4}$ treatment (Figure 2). 


\section{Histopathological examination}

Sections of the small intestine for control and WGO groups showed the normal architecture of healthy tissues including the intact mucosa, cylindrical glandular epithelium and the fingerlike villi structure (Figure 3 A, B).

Acute toxicity of $\mathrm{CCl}_{4}$ has reflected the complications in the architecture of small intestine including the loose structure of the mucous membrane (L), shortened and fractured villa $(\mathrm{S})$, and infiltration of the inflammatory cells into the lamina propria $(\mathrm{F})$.
In addition, intestine showed cystic dilatation of some intestinal glands (C) (Figure $3 \mathrm{C}$ ).

\section{DNA fragmentation}

Figure (4) showed that $\mathrm{CCl}_{4}$ produced marked intestinal DNA fragmentation below 50bp indicating the high apoptotic damaging effect of $\mathrm{CCl}_{4}$ compared to control and WGO groups. On the other hand, much less smear of fragmented DNA was detected in $\mathrm{CCl}_{4}+\mathrm{WGO}$ group when compared with intact DNA in the control group.
A
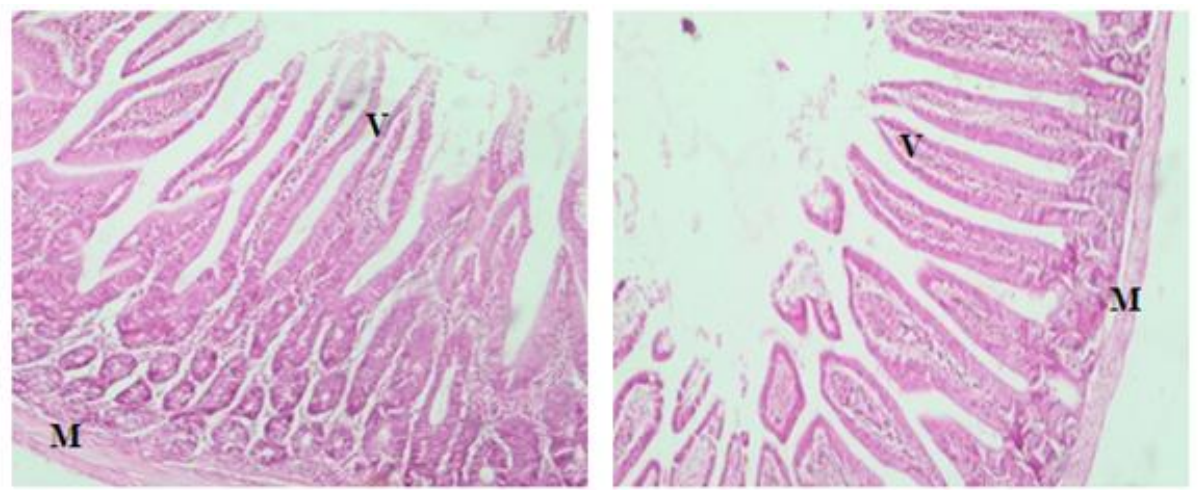

C

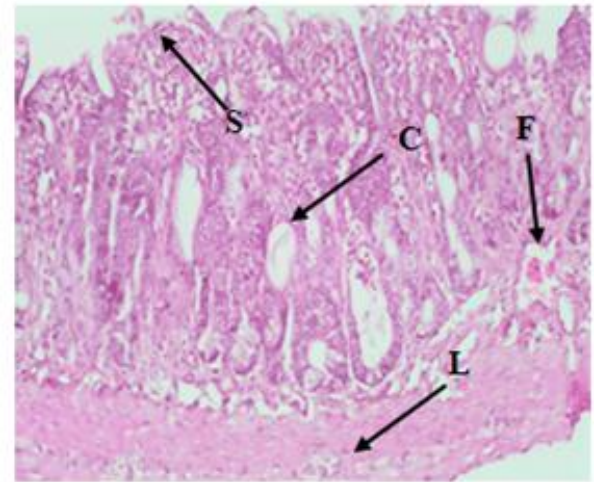

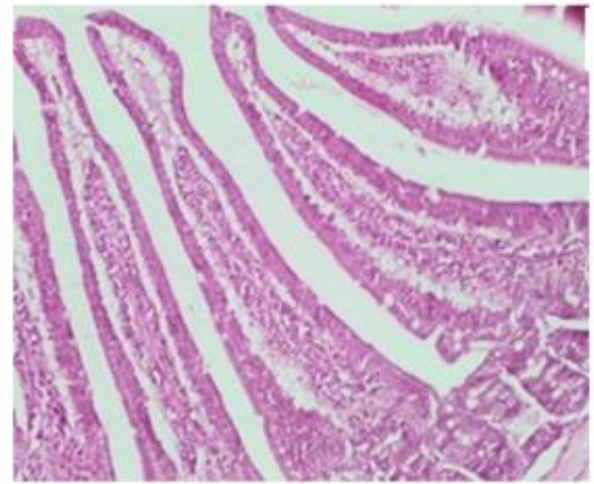

B

D

Fig. 3: Photomicrographs of intestinal tissues of mice stained with H\&E, (X 200). (A and B) control and WGO groups showing the normal architecture of intestinal tissues including the intact mucosa (M), cylindrical glandular epithelium and the finger-like villi structure (V). (C): CCl4-intoxicated mice, showed the loose structure of the mucous membrane $(\mathrm{L})$, shortened and fractured villa $(\mathrm{S})$, and infiltration of the inflammatory cells into the lamina propria (F). In addition, intestine showed cystic dilatation of some intestinal glands (C). (D): CCl4 + WGO groups showed healthy morphological and the structural shape of the small intestine.

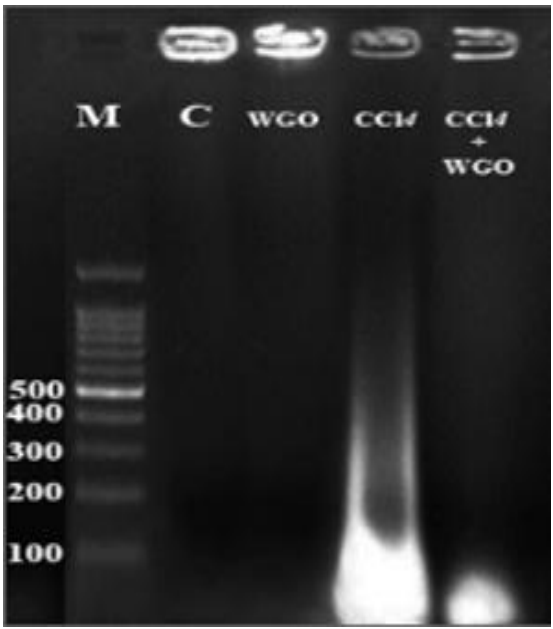

Fig. 4: DNA extracted from intestinal tissues of mice assessed by DNA fragmentation assay. Lane M: DNA ladder (low molecular weight ranges from 100-1000), C: DNA of control group, WGO: WGOtreated mice, $\mathrm{CCl}_{4}: \mathrm{CCl}_{4}$ intoxicated mice, $\mathrm{CCl}_{4}+$ WGO: $\mathrm{CCl}_{4}$ treated group followed by WGO administration. 
$\mathrm{CCL}_{4}$ was used for many years in experimental rodent models to induce hepatotoxicity at different levels including liver injury, fibrosis, cirrhosis, necrosis and hepatocellular carcinoma (HCC). The model of acute $\mathrm{CCl}_{4}$ - induced necrosis in the liver has been investigated after oral administration of $\mathrm{CCl}_{4}$ (LeSage et al., 1999). $\mathrm{CCl}_{4}$ is chemically lipophilic and diffuses simply across the cell membranes then gets distributed into the tissues (Ritesh et al., 2015). In $\mathrm{CCl}_{4}$ intoxicated mice, damage to the endoplasmic reticulum (ER) and accumulation of lipids occur in the hepatic cells (Jeon et al., 2003). Boll et al. (2001) reported that an increase in the esterification of free fatty acids of triglycerides (TG) and phospholipids occurred due to administration of $\mathrm{CCl}_{4}$ which in turn caused a disturbance in normal lipid homeostasis and consequently, lead to increase the levels of cholesterol synthesis.

In the present study, serum levels of total lipids, triglycerides, total cholesterol, LDL, and VLDL were significantly increased, while HDL level significantly decreased with the $\mathrm{CCl}_{4}$ administration in comparison to control group. These findings were in agreement with Kumar et al. (2007), they reported a hypercholesterolemia in $\mathrm{CC}_{4}$ intoxicated models, that was associated with failure of the liver. This condition was due to damage of the hepatic parenchymal cells that led to disturbance of total lipid metabolism in the liver (Raju et al., 2003). These effects were significantly reversed by oral administration of WGO to nearly the normal level in comparison to $\mathrm{CC}_{4}$ treated group. WGO is considered as a valuable source of monounsaturated and polyunsaturated fatty acids, including linoleic acid (omega-3 and omega-6) (Said et al., 2008). The monounsaturated fatty acid can reduce serum TG and phospholipid levels (Jenkins et al., 1999). In addition, WGO has a number of components with nutritional and health benefits, like high content of vitamin $\mathrm{E}$ and phytosterol. Those components might be the reason of decreasing the levels of both triglyceride and phospholipids. Moreover, WGO elevated the level of HDL-cholesterol that picks up and transports cholesterol in the blood back to the liver. That in turn leads to its elimination from the body and consequently reduces the harmful effects of LDL-cholesterol and decreases the incidence of atherosclerosis and cardiovascular diseases (Jonnala et al., 2005)

Multiple organ injuries are frequently assessed by the release of lactate dehydrogenase (LDH) activity in plasma. This study showed that LDH is elevated by 1.6 folds in mice subjected to $\mathrm{CCl}_{4}$ when compared to the control group. This finding may suggest that $\mathrm{CCl}_{4}$ not only damages the liver but also affects other organs. Administration of WGO might be responsible for the decrease of $\mathrm{LDH}$ level leakage, reduce the cell death and protect against organ damage induced by $\mathrm{CCl}_{4}$ (Zhu et al., 2013).

Previous study revealed that oxidative stress in the intestine of the cirrhotic liver might developed either by the generation of ROS in the mucosa or by possible inducers generated in the liver and transported into the intestinal lumen through the bile (Anup et al., 1999). The present study showed that even acute dose of $\mathrm{CCl}_{4}$ could generate marked (ROS)-induced intestinal damage through Xanthine Oxidase which is abundantly present in the intestinal mucosa (Anup et al., 1999).
$\mathrm{CCl}_{4}$ rapidly reaches the liver where it metabolized by cytochrome $\mathrm{P}_{450}$. It generates the highly reactive free radical $\mathrm{CCl}_{3}$ that initiates progression of lipid peroxidation of endoplasmic reticulum cell membrane that consequently, causes the formation of malondialdehyde (MDA) that in turn leads to damage in different organs (Ganie et al., 2011). The increase in MDA level in the small intestine leads to failure of the antioxidant mechanisms to prevent the generation of excessive free radicals through reduction of glutathione and superoxide dismutase in liver injury after administration of $\mathrm{CCl}_{4}$ (Ramachandran et al., 2002).

GSH is a tripeptide thiol that is abundant in the tissue and plays a vital role in protecting cells against peroxides and free radicals generated from toxic substances including $\mathrm{CCl}_{4}$ (Endo et al., 2013).

GST plays a significant role in cell defense against ROSmediated injury by detoxification of lipid hydro- peroxides that have been developed due to oxidative damage (Yang et al., 2001). The antioxidant enzymes such as CAT, SOD and non-enzymatic electron receptors such as GSH are affected and used as indexes to evaluate the level of oxidative stress. Ramachandran et al. (2002) mentioned that the reason of intestinal oxidative stress in liver treated with $\mathrm{CCl}_{4}$ are the increase in mucosal xanthine oxidase activity in conjunction with the decrease in the activity of antioxidant enzymes SOD and CAT. This was found in harmony with (Yang et al., 2001) who informed that injection with $\mathrm{CCl}_{4}$ induced significant reduction in GST that can initiate lipid peroxidation and DNA damage. The current study showed a significant increase in intestinal $\mathrm{NO}$ level after oral administration of $\mathrm{CCl}_{4}$ that reflects the imbalance between pro-oxidant and antioxidant activity which led to tissue injury (Hamouda et al., 2016).

In this study, acute dose of $\mathrm{CCl}_{4}$ caused a significant reduction in GSH, GST, SOD and CAT levels in the intestinal mucosa, along with a significant elevation in MDA and NO levels. The administration of WGO suppressed the generation of free radicals and increased the levels of intestinal endogenous antioxidants. The ameliorative effect of WGO is due to its high content of vitamin $\mathrm{E}$ that has the potency to inactivate the reactive free radicals, thus avoiding the propagation of the radical chain reaction (Ismael et al., 2014). WGO contains a high percentage of unsaturated $(81 \%)$ and numerous saturated fatty acids $64 \%$ that has anti-inflammatory properties and can decrease oxygen free radicals and nicotinamide adenine dinucleotide phosphate (NADPH) oxidase activity (Abd-El-Hameed et al., 2013). In addition, the phenolic compounds in WGO exhibit an antioxidant influence that could reduce the pro-oxidative state and give powerful antioxidant protection to different organs in the body (Durak et al., 2010).

$\mathrm{CCl}_{4}$ induced damage by over production of lipid peroxidation and generation of reactive oxygen species that attack and damage DNA leading to DNA hydroxylation. Several studies proved that the administration of $\mathrm{CCl}_{4}$ caused apoptosis and DNA damage in the liver (Wiseman et al., 1996; Aksit et al., 2014) .Our study demonstrated that $\mathrm{CCl}_{4}$ administration caused marked 
oxidative DNA damage in the small intestine through overproduction of ROS. WGO administration caused significant reduction of DNA fragmentation as a result of the ameliorative effect of WGO against ROS induced by $\mathrm{CCl}_{4}$ treatment.

This study showed morphological alterations in the architecture of intestinal tissue which reflect the pathophysiologic complications of the small intestine in response to acute administration of $\mathrm{CCl}_{4}$. Our findings showed a change of the intestinal epithelial barrier as a shortening of villi, cystic dilatation of glandular cells, infiltration of immune cell. The administration of WGO restored the integrity of the epithelial barrier and the healthy architecture of the small intestine through the reduction of the ROS and lipid peroxidation.

\section{CONCLUSION}

The results of the present study demonstrate that $\mathrm{CCl}_{4}$ caused liver hypercholesterolemia and hyperlipidemia as well as an increase in the atherosclerosis index. $\mathrm{CCl}_{4}$ caused damage to other organs such as small intestine through increasing the ROS, $\mathrm{NO}$, and oxidative stress. WGO administration has the potency to protect not only the liver but also the small intestine in acute $\mathrm{CCl}_{4}$ induced tissue damage. The valuable effect is chiefly attributed to its mechanism of reducing the lipid profile and suppressing the oxidative stress that caused DNA damage.

\section{Financial support and sponsorship: Nil.}

Conflict of Interests: There are no conflicts of interest.

\section{REFERENCES}

Abd-El-Hameed AMA, Soliman HA, and El-Reheem ESA. Protective Role of Wheat Germ Oil in Clozapine-Induced Oxidative Stress and Biochemical Alterations in Liver of male albino rats, Journal of American Science, 2013; 9.

Aebi H. Catalase in vitro, Methods in enzymology, 1984; 105:

$121-26$

Aksit $\mathrm{H}$, and Bildik A. Determination of DNA damage in experimental liver intoxication and role of $\mathrm{N}$-acetyl cysteine, Cell biochemistry and biophysics, 2014; 70: 1119-25.

Anup R, Aparna V, Pulimood A, Balasubramanian KA, Sussana $\mathrm{P}$, and Watkins P. Surgical stress and the small intestine: role of oxygen free radicals, Surgery, 1999; 125: 560-69.

Anwar M, and Mohamed N. Amelioration of liver and kidney functions disorders induced by sodium nitrate in rats using wheat germ oil, Journal of Radiation Research and Applied Sciences, 2015; 8: 77-83.

Bajaj JS, Hylemon PB, and Younossi Z. The intestinal microbiota and liver disease, The American Journal of Gastroenterology Supplements, 2012; 1: 9-14.

Beutler E, Duron O, and Kelly BM. Improved method for the determination of blood glutathione, The Journal of laboratory and clinical medicine, 1963; 61: 882-88.

Boll M, Lutz W, Becker E, and Stampfl A. Mechanism of carbon tetrachloride-induced hepatotoxicity. Hepatocellular damage by reactive carbon tetrachloride metabolites, Zeitschrift für Naturforschung C, 2001; 56: 649-59.

Dashti H, Jeppsson B, Hägerstrand I, Hultberg B, Srinivas U, Abdulla M, and Bengmark S. Thioacetamide-and carbon tetrachlorideinduced liver cirrhosis, European surgical research, 1989; 21: 83-91.

Durak D, Kalender S, Uzun F, Demir F, and Kalender Y. Mercury chloride-induced oxidative stress and the protective effect of vitamins $\mathrm{C}$ and $\mathrm{E}$ in human erythrocytes in vitro, Afr J Biotechnol, 2010; 9: 488-95.

Endo H, Niioka M, Kobayashi N, Tanaka M, and Watanabe T. Butyrate-producing probiotics reduce nonalcoholic fatty liver disease progression in rats: new insight into the probiotics for the gut-liver axis, PLoS One, 2013; 8: 6388.

Essawy AE, Abdel-Moneim AM, Khayyat LI, and Elzergy AA. Nigella sativa seeds protect against hepatotoxicity and dyslipidemia induced by carbon tetrachloride in mice, Journal of Applied Pharmaceutical Science, 2012; 2: 21.

Friedewald WT, Levy RI, and Fredrickson DS. Estimation of the concentration of low-density lipoprotein cholesterol in plasma, without use of the preparative ultracentrifuge, Clinical chemistry, 1972; 18: 499 502 .

Ganie SA, Haq E, Hamid A, Qurishi Y, Mahmood Z, Zargar BA, Masood A, and Zargar MA. Carbon tetrachloride induced kidney and lung tissue damages and antioxidant activities of the aqueous rhizome extract of Podophyllum hexandrum, BMC complementary and alternative medicine, 2011; 11: 17 .

Gelmez N, Kincal NS, and Yener ME. Optimization of supercritical carbon dioxide extraction of antioxidants from roasted wheat germ based on yield, total phenolic and tocopherol contents, and antioxidant activities of the extracts, The Journal of Supercritical Fluids, 2009; 48: 217-24

Go J, Kim JE, Koh EK, Song SH, Sung JE, Lee HA, Lee YH, Lim Y, Hong JT, and Hwang DY. Protective Effect of gallotanninenriched Extract isolated from Galla rhois against CCl4-induced hepatotoxicity in ICR mice, Nutrients, 2016; 8: 107.

Gutiérrez R, Alvarado JL, Presno M, Pérez-Veyna O, Serrano $\mathrm{CJ}$, and Yahuaca P. Oxidative stress modulation by Rosmarinus officinalis in $\mathrm{CCl}_{4}$-induced liver cirrhosis, Phytotherapy Research, 2010; 24: 595601.

Habig WH, Pabst MJ, and Jakoby WB. Glutathione Stransferases the first enzymatic step in mercapturic acid formation, Journal of biological Chemistry, 1974; 249: 7130-39.

Hamouda AF, Sameeh MY, and Shrourou RM. Effect of Avocado (Persea Americana), Cabbage (Brassica Oleracea) and Ginger (Zingiber Officinale) on Rat Liver and Thyroid Injuries Induced by $\mathrm{CCl} 4$ (Carbon Tetrachloride), Journal of Pharmacy and Pharmacology, 2016; 4: 108-18.

Ismael OE, Hashish EA, and Ali HA. Lipid Profile and Lipogensis Following Corn Oil, Truffle Oil or Wheat Germ Oil Administration in Albino Rat, Global Veterinaria, 2014; 12: 461-69.

Jenkins DJ, Kendall CW, Vuksan V, Augustin LS, Mehling C, Parker T, Vidgen E, Lee B, Faulkner D, and Seyler H. Effect of wheat bran on serum lipids: influence of particle size and wheat protein, Journal of the American College of Nutrition, 1999; 18: 159-65.

Jeon TI, Hwang SG, Park NG, Jung YR, Im Shin S, Choi SD, and Park DK. Antioxidative effect of chitosan on chronic carbon tetrachloride induced hepatic injury in rats, Toxicology, 2003; 187: 67-73.

Jonnala R, Dunford N, and Irmak S. 2005. "Policosanol, tocopherol and phytosterol composition of wheat extracts as affected by extraction methods. Institute of Food Technologists Annual Meeting, New Orleans." In IFT Annual Meeting, July, 15-20.

Karabacak M, Kanbur M, Eraslan G, and Sarica ZS. The antioxidant effect of wheat germ oil on subchronic coumaphos exposure in mice, Ecotoxicology and environmental safety, 2011; 74: 2119-25.

Kumar SS, Kumar BR, and Mohan GK. Antihepatotoxic activity of Trichosanthes cucumerina on carbon tetrachloride induced liver damage in rats, Pharmacologyonline, 2007; 3: 461-69.

Leenhardt F, Fardet A, Lyan B, Gueux E, Rock E, Mazur A, Chanliaud E, Demigné C, and Rémésy C. Wheat germ supplementation of a low vitamin $\mathrm{E}$ diet in rats affords effective antioxidant protection in tissues, Journal of the American College of Nutrition, 2008; 27: 222-28.

LeSage GD, Benedetti A, Glaser S, Marucci L, Tretjak Z, Caligiuri A, Rodgers R, Phinizy JL, Baiocchi L, and Francis H. Acute carbon tetrachloride feeding selectively damages large, but not small, cholangiocytes from normal rat liver, Hepatology, 1999; 29: 307-19. 
Liu X, Zheng X, Song Z, Liu X, kumar Kopparapu N, Wang X, and Zheng Y. Preparation of enzymatic pretreated corn gluten meal hydrolysate and in vivo evaluation of its antioxidant activity, Journal of Functional Foods, 2015 18: 1147-57.

Llovet J, Bartoli R, Planas Re, Cabre E, Jimenez M, Urban A, Ojanguren I, Arnal J, and Gassull M. Bacterial translocation in cirrhotic rats. Its role in the development of spontaneous bacterial peritonitis, Gut, 1994; 35: 1648-52.

Majzoobi M, Ghiasi F, and Farahnaky A. Physicochemical assessment of fresh chilled dairy dessert supplemented with wheat germ, International Journal of Food Science \& Technology, 2016; 51: 78-86.

Manevska B. [Enzymatic changes in the mucous membrane of the small intestine in tetrachlormethane-induced experimental liver cirrhosis], Eksperimentalna meditsina i morfologiia, 1975; 15: 107-11.

Meyer A. An attempt at analysis of the neurotic constitution, The American Journal of Psychology, 1903; 14: 90-103.

Montgomery H, and Dymock J. Colorimetric determination of nitric oxide, Analyst, 1961; 86: 414-17.

Nishikimi M, Rao NA, and Yagi K. The occurrence of superoxide anion in the reaction of reduced phenazine methosulfate and molecular oxygen, Biochemical and biophysical research communications, 1972; 46: 849-54.

Ohkawa $\mathrm{H}$, Ohishi N, and Yagi K. Assay for lipid peroxides in animal tissues by thiobarbituric acid reaction, Analytical biochemistry, 1979; 95: 351-58.

Raju K, Anbuganapathi G, Gokulakrishnan V, Rajkapoor B, Jayakar B, and Manian S. Effect of dried fruits of Solanum nigrum LINN against CCl4-induced hepatic damage in rats, Biological and Pharmaceutical Bulletin, 2003; 26: 1618-19.

Ramachandran A, Prabhu R, Thomas S, Reddy JB, Pulimood A, and Balasubramanian KA. Intestinal mucosal alterations in experimental cirrhosis in the rat: role of oxygen free radicals, Hepatology, 2002; 35: $622-29$.

Risal P, Hwang PH, Yun BS, Yi H-K, Cho BH, Jang KY, and Jeong YJ. Hispidin analogue davallialactone attenuates carbon tetrachloride-induced hepatotoxicity in mice, Journal of natural products, 2012; 75: 1683-89.

Ritesh K, Suganya A, Dileepkumar H, Rajashekar Y, and Shivanandappa T. A single acute hepatotoxic dose of $\mathrm{CCl} 4$ causes oxidative stress in the rat brain, Toxicology Reports, 2015; 2: 891-95.

Said UZ, Saada HN, Mahdy E-SM, Shousha WG, and Shedid SM. Wheat germ oil attenuates gamma radiation-induced skeletal muscles damage in rats. Egyptian Journal of Biochemistry \& Molecular Biology, 2008; 26: 101-18.

Sambrook J, Fritsch EF, and Maniatis T. 1989. Molecular Cloning: A Laboratory Manual, $2^{\text {nd }}$ ed., (Cold spring harbor laboratory press, New York).
Srivastava A, and Shivanandappa T. Hepatoprotective effect of the root extract of Decalepis hamiltonii against carbon tetrachlorideinduced oxidative stress in rats, Food Chemistry, 2010; 118: 411-17.

Stein Y, and Shapiro B. Uptake and metabolism of triglycerides by the rat liver, Journal of lipid research, 1960; 1: 326-31.

Tietz PS, Holman RT, Miller LJ, and LaRusso NF. Isolation and characterization of rat cholangiocyte vesicles enriched in apical or basolateral plasma membrane domains, Biochemistry, 1995; 34: 1543643.

Van der Heiden C, Bais R, Gerhardt W, Lorentz K, and Rosalki S. Approved recommendation on IFCC methods for the measurement of catalytic concentration of enzymes. Part 8. IFCC method for lactate dehydrogenase, Eur J Clin Chem Clin Biochem, 1994; 32: 639-55.

Watkins P. Role of xanthine oxidase in small bowel mucosal dysfunction after surgical stress (Br J Surg 2000; 87: 1094-1101), British Journal of Surgery, 2001; 88: 152-53.

Weber LW, Boll M, and Stampfl A. Hepatotoxicity and mechanism of action of haloalkanes: carbon tetrachloride as a toxicological model, Critical reviews in toxicology, 2003; 33: 105-36.

Wiseman $\mathrm{H}$, and Halliwell B. Damage to DNA by reactive oxygen and nitrogen species: role in inflammatory disease and progression to cancer, Biochemical Journal, 1996; 313: 17.

Yang Y, Cheng J-Z, Singhal SS, Saini M, Pandya U, Awasthi S, and Awasthi YC. Role of glutathione S-transferases in protection against lipid peroxidation overexpression of HGSTA2-2 in K562 cells protects against hydrogen peroxide-induced apoptosis and inhibits JNK and caspase 3 activation, Journal of biological Chemistry, 2001; 276: 1922030 .

Zhu K-X, Guo X, Guo X-N, Peng W, and Zhou H-M. Protective effects of wheat germ protein isolate hydrolysates (WGPIH) against hydrogen peroxide-induced oxidative stress in PC12 cells, Food research international, 2013; 53: 297-303.

Zöllner N, and Kirsch K. Colorimetric method for determination of total lipids, Fur Gesampte Exp Med, 1962; 135: 545.

\section{How to cite this article:}

Hanan Saleh. Modulatory Effect of Wheat Germ Oil on Intestinal Oxidative Stress and DNA damage Induced by Carbon tetrachloride in Mice. J App Pharm Sci, 2016; 6 (12): 067-074. 